\title{
A UNIFORMIZAÇÃO DA JURISPRUDÊNCIA TRABAHLISTA DIANTE DA REFORMA: UMA CRÍTICA AOS DISCURSOS DA MODERNIZAÇÃO E DA SEGURANÇA JURÍDICA
}

\author{
Almiro Eduardo de Almeida* \\ Simbard Jones Ferreira Lima**
}

\section{INTRODUÇÃO}

Dois dos principais argumentos dos defensores da chamada "Reforma Trabalhista" são a modernização das relações de trabalho e a necessidade que a economia tem de segurança jurídica. "Modernização" e "segurança jurídica" tornaram-se mantras, repetidos em quase todos os discursos de defesa das alterações legislativas no âmbito do Direito do Trabalho. A falácia existente nesses discursos vem sendo denunciada em inúmeras publicações justrabalhistas desde ainda antes da aprovação da Lei noㅡ

\footnotetext{
* Juiz do Trabalho vinculado ao Tribunal Regional do Trabalho da 4⿳亠丷a Região, Professor de Graduação no Centro Universitário Metodista - IPA, Especialista em Direito do Trabalho pela Universidad de la República Oriental del Uruguay, Mestre em Direitos Sociais e Políticas Públicas pela Universidade de Santa Cruz do Sul - UNISC, Doutor em Direito do Trabalho pela Universidade de São Paulo - USP, Coordenador do Grupo de Pesquisa sobre Direito do Trabalho do Centro Universitário Metodista - IPA.

** Mestre em Direito pela Universidade de Santa Cruz do Sul - UNISC. Especialista em Direito Civil e Processual Civil pela Faculdade IDC e em Direito Penal e Processual Penal pela Faculdade IDC. Professor Assistente na Universidade DE Santa Cruz do Sul nos Cursos de Graduação e Pós-Graduações Lato Sensu. Advogado com ampla atuação no Direito do Trabalho.
} 
13.467/2017. Somando-se a essa linha crítica, o presente artigo visa abordar a questão específica da tentativa de limitação do poder de interpretação e uniformização da jurisprudência que se pretende impor aos tribunais trabalhistas, especialmente pela inclusão do parágrafo $2^{\circ}$ no artigo $8^{\circ}$ da CLT e alteração da alínea f do inciso I do artigo 702 do mesmo diploma legal.

Os dispositivos em questão visam limitar a criação e a alteração de súmulas e outros enunciados de jurisprudência no âmbito da Justiça do Trabalho. Por um lado, atuam na materialidade de tais enunciados, vedando que restrinjam direitos ou criem obrigações não previstos em lei; por outro, buscam dificultar excessivamente o procedimento de sua edição e alteração. A primeira vista, os dispositivos podem até parecer interessantes, uma vez que, súmulas e outros enunciados de jurisprudência editados por tribunais efetivamente não devem servir para restringir direitos e/ou criar obrigações não previstos em lei. Ou seja, tais enunciados não têm, ou pelo menos não deveriam ter, a finalidade de inovar o Ordenamento Jurídico, mas apenas de sedimentar interpretações acerca de leis e outros comandos normativos, atribuindo certo grau de estabilidade (segurança jurídica) ao Direito. Há de se considerar, por outro lado, que, sendo um fenômeno social, o direito deve guardar certa dinâmica. Daí a necessidade de, para assegurar a própria manutenção do sistema jurídico, encontrar-se um ponto de equilíbrio entre a estabilidade e a dinâmica jurídicas.

Evidenciando não se tratar tão-somente de uma disputa ideológica, admitimos como premissa do presente artigo adotar a própria ideologia dominante. Para realizar nossa crítica não utilizaremos nenhum discurso dito "de esquerda", ou "socialista", mas tão-somente os discursos admitidos, defendidos e inclusive utilizados pelos próprios defensores da "Reforma". Com isso, queremos deixar claro que a crítica que segue não se esgota em disputas ideológicas, mas segue a racionalidade do próprio 
discurso dominante. Trata-se, pois, de uma crítica imanente ao próprio sistema.

Para abandonar a superfície do mero debate ideológico-político, optamos por aprofundar a discussão jurídica sob o seu aspecto filosófico, adentrando nos meandros da filosofia do Direito. Partimos de uma visão positivista do Direito, resgatando a sua gênese cientificista herdeira da modernidade. Em seguida, fizemos uma breve apresentação da contemporânea busca de superação do dogma positivista a partir de diferentes matrizes ditas "pós-positivistas". Finalmente examinamos a qual visão de mundo melhor se adequa a função dos tribunais pretendida pelas alterações legislativas realizadas pela "Reforma".

\section{O CIENTIFICISMO E A VISÃO POSITIVISTA DO DIREITO}

Antes de abordarmos o positivismo jurídico propriamente dito, importante se faz contextualizar o movimento positivista, que está relacionado, dentre outros fatores, ao avanço científico e tecnológico que foi a mola propulsora das significativas transformações das sociedades da época. Destaca-se, assim, como os principais responsáveis pela mencionada revolução do conhecimento humano Galileu Galilei, René Descartes e Isaac Newton.

O arcabouço conceitual criado por Galileu e Descartes - o mundo como uma máquina perfeita governada por leis matemáticas exatas - foi completado de maneira triunfal por Isaac Newton, cuja grande síntese, a mecânica newtoniana, foi a realização que coroou a ciência do século XVII. ${ }^{1}$

A partir de então, a pauta do desenvolvimento de todo e qualquer conhecimento possui como centro a ciência, vez que "o universo material, incluindo os organismos vivos, era uma má-

CAPRA, Fritjof. A Teia da Vida - Uma Nova Compreensão Científica dos

Sistemas Vivos. São Paulo: Cultrix, 1996, p. 34. 
quina (para Descartes), e poderia ser entendido completamente, analisando-o em termos de suas menores partes". ${ }^{2}$ Com a ascensão dessa espécie de "saber científico", as explicações de todos os fenômenos, não apenas naturais, mas também sociais, devem passar por sua análise físico-descritiva, afastando-se das pesquisas metafísicas que até então reinavam as tentativas de explicação.

Neste contexto é que se encontra o positivismo jurídico, que possui como corolário a análise e sistematização jurídica, donde se possas extrair as normas válidas em termos de uma totalidade fechada e acabada. Reduz-se, assim, o Direito às normas positivadas, com a desconsideração das questões éticas, políticas e sociológicas na esfera do Direito. ${ }^{3}$

Reflexo do positivismo científico do século XIX, o positivismo jurídico, como movimento de pensamento antagônico a qualquer teoria naturalista, metafísica, sociológica, histórica, antropológica etc. adentrou de tal forma nos meandros jurídicos que suas concepções se tornaram estudo indispensável e obrigatório para a melhor compreensão lógico-sistemática do Direito. Sua contribuição é notória no sentido que fornece uma dimensão integrada e científica do Direito, porém, a metodologia do positivismo jurídico identifica que o que não pode ser provado racionalmente não pode ser conhecido; sem dúvida nenhuma, retira os fundamentos e as finalidades, contentando-se com o que ictu oculi satisfaz às exigências da observação e da experimentação, daí restringir-se ao posto. ${ }^{4}$

Citamos como expoente do movimento positivista Hans Kelsen, tendo em vista a extensão e significação de sua obra, marcada pelo esforço de afirmação delimitativa de uma Ciência do Direito

2 Idem, p. 35.

3 BITTAR, Eduardo C. B.; ALMEIDA, Guilherme Assis de. Curso de Filosofia do Direito. $-2^{\text {a }}$ ed. São Paulo: Atlas, 2002, p. 329.

4 Idem, p. 336 
desprovida de qualquer influência que lhe fosse externa, o que imporia seu reconhecimento como ciência autônoma.

O sistema jurídico, para Kelsen, é unitário, orgânico, fechado, completo e auto-suficiente; nele, nada falta para o seu aperfeiçoamento; normas inferiores buscam seu fundamento de validade em normas hierarquicamente superiores. 0 ordenamento jurídico resume-se a esse complexo emaranhado de relações normativas. Qualquer abertura para fatos exteriores comprometeria sua rigidez e completude... ${ }^{5}$

Como podemos perceber, na tentativa de construção de uma teoria pura do Direito, Kelsen pende à legitimação da norma abstraída de seu cunho substancial vinculatório, bem como aos aspectos sociais que a envolvem, reportando-se somente a seu fundamento de competência, que esgotaria em si mesmo o próprio fundamento de validade. 0 que, em certo ponto, de acordo com Streck e Morais, destoa da essência do Estado de Direito, mas aproxima-se de um Estado Legal ${ }^{6}$. Para Kelsen, a ciência jurídica não é a ciência dos fatos, de dados concretos, de acontecimentos, de atos sociais, mas a ciência do "dever-ser", ou seja, a ciência que procura descrever o funcionamento e o maquinismo das normas jurídicas (como bem característico da filosofia cartesiana). ${ }^{7}$

A garantia dos direitos "naturais" do homem, pela sua positivação, como finalidade precípua do Estado acentua a distinção do Estado de Direito Liberal frente ao modelo absolutista, o que passa, assim, a justificar a limitação jurídica do Poder. Assim, a proteção de direitos sobrepõe-se à forma como estruturados os

$5 \quad$ Idem, p. 338.

6 STRECK, Lênio Luiz; MORAIS, José Luis Bolsan de. Ciência Política e Teoria Geral do Estado. $3^{\text {a }}$ ed. - Porto Alegre : Livraria do Advogado, 2003, p. 88.

7 BITTAR, Eduardo C. B.; ALMEIDA, Guilherme Assis de. Curso de Filosofia do Direito. $-2^{a}$ ed. São Paulo: Atlas, 2002. P. 342. 
poderes. Aprofundando tal referência, podemos dizer que há, neste formato estatal, além da vinculação dos atos emanados do Poder Público à Lei (Princípio da Legalidade - característico do Estado Legal). Desta forma, temos que o Estado Liberal de Direito atrela-se à restrição da ação do Estado, através da imposição de limitações jurídico-legal negativas, destacando-se a primazia da lei escrita, o princípio da separação funcional dos Poderes e, primordialmente, a proteção de direitos fundamentais ditos de primeira geração ${ }^{8}$.

Neste passo, as restrições ao exercício do poder encontram eco na ampla positivação do Direito, representando um dos corolários da visão liberal-individualista, no que se viu instrumento propício à produção dos resultados buscados pela burguesia ascendente? .

Na gênese da Civil Law, pois, "é notada a preocupação com uma ordem racional de conceitos, aparecendo o Direito como um sistema: um conjunto de preceitos que deveriam estar agrupados [...]" 10

O centro das atenções jurídicas estava voltado para o direito positivado em diplomas codificados - completos, insusceptíveis de interferência axiológica - enquanto que às Constituições restava o papel de veicular as garantias formais:

Organizar os poderes e traçar a linha das competências indispensáveis ao seu correto e efetivo funcionamento fora anteriormente a preocupação dominante das forças e correntes mais conservado-

8 MORAIS, José Luis Bolzan de. Do Direito Social aos Interesses Transindividuais: o Estado e o Direito da ordem contemporânea. Porto Alegre: Livraria do Advogado, 1996, p. 70.

9 SARLET, Ingo Wolfang (org); FINGER, Júlio César. A Constituição Concretizada - Construindo Pontes com o Público e o Privado. Porto Alegre: Livraria do Advogado, 2000, p. 88.

10 SOARES, Guido Fernando Silva. Common Law - Introdução ao Direito dos EUA. 2. ed. São Paulo : RT, 2000, p. 27. 
ras que circulavam no constitucionalismo da idade liberal, sobretudo em França, durante a secunda metade deste século; tal preocupação, todavia, ainda se exprime no pensamento constitucional. Um jurista e cientista político do quilate de Burdeau, até há pouco, não tinha a Constituição por "direito", mas por "idéia", e, em razão disso, não a levava tão a sério como devia, conforme inculcou muito bem, recentemente, o publicista Favoreu. ${ }^{11}$

Importa compreender, sobretudo, que esse receituário liberal não era neutro. Tendo como fundamento o culto à racionalidade cientificista, objetivava a ascensão política da classe que, então, já detinha o poder econômico-social: a burguesia. Com a derrocada do modelo absolutista, e as demais mudanças resultantes da ascensão burguesa, impulsionada por fatores econômicos e sociais, mas também filosóficos e culturais, ganha especial relevo a afirmação da nova forma estatal. 0 Estado Liberal de Direito ergue-se, inicialmente, com o estabelecimento das diretrizes essenciais do ideário liberal (econômico), cuja legitimação jurídica encontra-se, especialmente, na substituição das correntes jusnaturalistas pelo juspositivismo:

Em vez da tradição, o contrato social; em vez da soberania do príncipe, a soberania nacional e a lei como expressão da vontade geral; em vez do exercício do poder por um só ou seus delegados, o exercício por muitos, eleitos pela colectividade; em vez da razão do Estado, o Estado como executor de normas jurídicas; em vez de súditos, cidadãos, e atribuição a todos os homens, apenas por serem homens, de direitos consagrados nas leis. ${ }^{12}$

11 BONAVIDES, Paulo. Curso de Direito Constitucional. 7a ed. - São Paulo: Malheiros Editores, 1997. P. 537 e 538.

12 MIRANDA, Jorge. Manual de Direito Constitucional, tomo I, 4. ed. revista e atualizada. Coimbra: Coimbra Editora Ltda., 1990, p. 83. 
Verifica-se, assim, a contextualização da teoria positivista com os demais avanços experimentados pela dita Revolução Científica. A busca de segurança e de explicações, portanto, embasaram o reducionismo de que foi alvo a Ciência do Direito. Não há como se negar a importância de tal estruturação para uma determinada forma de compreensão do Direito, todavia com muitos reflexos negativos, especialmente no que diz respeito à atuação do intérprete-aplicador.

[...] a noção de sistema foi a maior contribuição do racionalismo para o Direito (F. Amaral:66-68). Mas, qual é o sistema que propunha a codificação? Tratava-se de um sistema fechado, axiomático-dedutivo, em que a atividade do intérprete resumia-se a isolar o fato e identificar a norma jurídica a ele aplicável, como se fosse tal atividade uma operação lógico-formal. ${ }^{13}$

Sobre os limites do intérprete-aplicador da norma, é famosa a analogia que Kelsen, o maior dos expoentes do juspositivismo, faz da decisão judicial que deve ficar restrita como um quadro em sua moldura. ${ }^{14}$ A principal preocupação de Kelsen, no entanto, não era com a intepretação da lei, mas sim com a própria lei, sua estrutura e dinâmica. A positivação do Direito, assim, também passa a ser um dos corolários do codicismo jurídico. A redução do direito ao que está escrito nos códigos não é neutra de valores, mas representa típica visão liberal-individualista, constituindo-se em instrumento propício à produção dos resultados buscados pela burguesia ascendente.

13 SARLET, Ingo Wolfang (org); FINGER, Júlio César. A Constituição Concretizada - Construindo Pontes com o Público e o Privado. Porto Alegre : Livraria do Advogado, 2000.. P. 88.

14 KELSEN, Hans. Teoria pura do direito. São Paulo: Martins Fontes, 2006, p. 394. O esquema foi apresentado de forma bem clara no artigo 11, p. 254-5 
Em torno dos códigos,[...], floresceu a denominada 'escola da exegese', que se debatia em torno da literalidade dos textos legais, na idéia de que nestes estariam as soluções para todos os fatos que o direito se propunha a regular. Conexa à concepção sistemática formal-dedutiva, e na medida do fortalecimento do Estado Moderno, foi se firmando o dogma da completude. Monopolizando o Estado, a produção normativa, e para manter essa onipotência, punha-se o código para o juiz como um prontuário que lhe deveria servir infalivelmente, e do qual não poderia afastar-se. Esse modelo satisfazia, como menciona Gomes Canotilho, às "estratégias burguesas da legalidade", não somente na medida que fornecia a certeza do direito, mas também porque propiciava uma aplicação da justiça uniforme em todo o território estatal, condições necessárias para a operacionalização da economia de mercado ajustada ao moderno Estado nacional. As Constituições, enquanto os códigos se transformaram no centro do sistema jurídico, ficaram reduzidas a simples "leis orgânicas dos poderes políticos". ${ }^{15}$

O movimento positivista representa, pois, a um só tempo, herança histórica do cientificismo-mecanicista moderno e fundamento jurídico de sustentação do modelo econômico liberal. Dando forma inicial ao Estado de Direito, caracterizou-se, em um primeiro momento, pelo radical rompimento com a ordem absolutista até então vigorante, vindo, portanto, a estabelecer a limitação jurídica do Estado a partir da lei escrita ${ }^{16}$, retrato fiel da vontade geral (já que todo poder emana do povo), conforme o ideário burguês da época.

15 SARLET, Ingo Wolfang (org); FINGER, Júlio César. A Constituição Concretizada - Construindo Pontes com o Público e o Privado. Porto Alegre : Livraria do Advogado, 2000. P. 88.

16 LEAL, Mônia Clarissa Hennig. Jurisdição Constitucional Aberta: Reflexões sobre a Legitimidade e os Limites da Jurisdição Constitucional na Ordem Democrática - uma Abordagem a Partir das Teorias Constitucionais Alemã e Norte- Americana. Rio de Janeiro: Lumen Juris, 2007. 
Deste modo, a positivação do Direito representou grande avanço com relação ao modelo anterior, já que ganha novo status, agora de ciência autônoma, o que é reconhecidamente um avanço para a sociedade moderna ${ }^{17}$. Todavia, a exacerbação de tal teoria fulminou com seu cultuamento e engessamento do sistema, motivo pelo qual a função judicante passou a necessitar de novos instrumentos jurídicos para a realização do ideal de Justiça. A fim de equilibrar as necessidades contraditórias de dinâmica e estabilidade jurídicas, os juízes passam a utilizar modelos interpretativos que ultrapassaram o simples silogismo declarativo. Com isso, o intérprete-aplicador passa a exercer não apenas uma função declarativa da norma, mas também, de certa forma, criativa. É nesse contexto que tribunais passam a editar súmulas e enunciados de jurisprudência capazes, a um só tempo, de conferir a melhor interpretação a cada dispositivo normativo e de garantir uma mínima segurança jurídica pela via da uniformização de decisões. É justamente dessa nova função, inserida em uma nova mentalidade acerca do Direito, que passaremos a tratar na próxima seção.

\section{AS CONTEMPORÂNEAS TENTATIVAS DE SUPERAÇÃO DO DOGMA POSITIVISTA E O LUGAR DE DESTAQUE DO INTERPRETE.}

A despeito de ter promovido significativa contribuição na concepção do Direito como ciência, o positivismo jurídico não atende mais aos ditames hodiernos, principalmente quando se menciona alguns acontecimentos, como, por exemplo: (i) as descobertas sobre as correntes científicas de cunho cartesiano,

17 LUHMANN, Niklas. Legitimação pelo Procedimento. Trad. Tércio Sampaio Ferraz Jr. Brasília: Editora Universidade de Brasília, s.d., p. 24: “[...] o conceito de verdade no contexto de desenvolvimento das ciências e, vinculado a fortes pressupostos metodológicos, decompôs, por esse meio, os pensamentos de direito natural, positivando o direito, quer dizer, fundamentando-o em torno dos processos de decisão." 
uma vez que as respostas absolutas que compreendiam este conhecimento aplicado cederam espaço à relatividade da Teoria Quântica, o que impôs uma interpretação sistêmica de todas as construções científicas ${ }^{18}$; (ii) o fato de as Constituições, com o avanço da positivação dos direitos de segunda geração, auferirem um novo patamar hermenêutico, pois muito mais do que garantias formais de separação entre o Estado e a Sociedade, passaram a conter positivados valores conformadores e, portanto, caracterizando-se com intenso conteúdo material ${ }^{19}$; (iii) a transmutação, através da escola pós-positivista, a um efetivo caráter vinculante de tais valores ${ }^{20}$; (iv) o desenvolvimento da idéia de um Estado Democrático de Direito $^{21}$; (v) as transformações de que fora objeto a linguagem com a inclusão, em sua análise, do fator pragmático ${ }^{22}$.

Por tais razões, a contemporaneidade apresenta uma série de matrizes teóricas incumbidas da busca de superação dos dogmas positivistas e supressão de suas falhas. Em primeiro lugar, não se pode deixar de referir os avanços na Teoria do Direito, especialmente após a teoria da Legitimação pelo Procedimento, de Niklas Luhmann, bem como pela forte reformulação trazida pela teoria de Ronald Dworkin.

Acompanhando as alterações de concepção sobre o Direito, também se modificaram as formas de sua aplicação. Daí a importante inserção dos estudos que estão sendo realizados pela

18 CAPRA, Fritjof. A Teia da Vida - Uma Nova Compreensão Científica dos Sistemas Vivos. São Paulo: Cultrix, 1996. P. 46.

19 BONAVIDES, Paulo. Curso de Direito Constitucional. 7a ed. - São Paulo: Malheiros Editores, 1997. P. 584 e 585

20 ESPÍNDOLA, Ruy Samuel. Conceitos de Princípios Constitucionais - Elementos Teóricos para uma Formulação Dogmática Constitucionalmente Adequada. $1^{a}$ ed. 2 tir. São Paulo: Editora Revista dos Tribunais, 1999. P. 58-59.

21 STRECK, Lênio Luiz; MORAIS, José Luis Bolsan de. Ciência Política e Teoria Geral do Estado. $3^{a}$ ed. - Porto Alegre: Livraria do Advogado, 2003. P. 92.

22 REALE, Miguel. Teoria Tridimensional do Direito. $-5^{\text {a }}$ ed. Ver. e aum.. - São Paulo: Saraiva, 1994. P. 62. 
Escola da Hermenêutica Filosófica. Até porque se parte para a compreensão do Direito como sistema aberto e em constante transformação, decorrente do influxo de carga valorativa democrática e da participação ativa do jurista no processo de criação da norma específica para o caso concreto.

Em que pese o reconhecimento inicial da relevância da teoria Kelseneana, Luhmann avança principalmente porque vê grande equívoco na não utilização de fatores empíricos e filosóficos no objeto de estudo jurídico. Assim, através da inclusão de tais fatores, demonstra-se que mesmo o Direito positivado - necessário como forma de redução das complexidades sociais - pode alcançar posições diversas sobre os problemas jurídicos, sem que com isto se afete a presunção de justiça, que é alcançada através do procedimento.

De forma muito clara, assim, reconstrói-se a Teoria do Direito com base em um processo dinâmico, já que "um procedimento não pode ser considerado como uma sequência fixa de ações determinadas"23, não obstante a importância da ritualística para obtenção de segurança jurídica.

Assim, em que pese partir da existência de normas que estruturem os processos, aponta-se para a existência de novos conflitos e incertezas no interior do próprio procedimento. Deste modo, reconhecendo vários fatores sociais relacionados a processos de interação, passa a se entender que há, mesmo que em reduzido âmbito, espaço para a alteração de interpretação das normas dentro do processo, através da atuação dos indivíduos. ${ }^{24}$

23 LUHMANN, Niklas. Legitimação pelo Procedimento. Trad. Tércio Sampaio Ferraz Jr. Brasília: Editora Universidade de Brasília, s.d., p. 37.

24 Idem, p. 24: "Naturalmente que as normas jurídicas são pré-estabelecidas e permanecem constantes. Ao lado delas, porém existem expectativas de comportamento normativo social, regras do jogo da interação, de cujo observância depende a relação dos participantes, apoiando-se ou sancionando-se mutuamente e em cuja direção se dirigirá e assim, a história do processo legal”. 
A teoria ora exposta representa grande progresso com relação à teoria positivista, porquanto insere em seu objeto fatores sociológicos, que demonstram com cientificidade o desacerto de posições estandardizadas, porquanto o procedimento em que se constrói o Direito, seja na legislação ou mesmo na aplicação, sofre mudanças em razão da atuação dos envolvidos no processo.

Ainda com relação ao progresso experimentado pela Teoria do Direito, não menos importante é o estudo desenvolvido por Dworkin, que também traz grandes críticas ao Positivismo Jurídico. Utilizando uma linguagem metafórica, estudam-se as várias formas de como deve ser utilizado o vasto poder hermenêutico atribuído ao intérprete-aplicador. Insere-se, assim, no objeto de abrangência do Direito a ideia democrática de representatividade e da necessidade de adaptação do Direito aos valores atuantes no momento de sua aplicação. Neste sentido, questiona-se o próprio estágio democrático quando da formulação das normas, que poderia não ser suficientemente avançado a ponto de "oferecer um argumento democrático de equidade que nos permita considerar as opiniões concretas dos legisladores como bons indícios de qual era a opinião pública da época". ${ }^{25}$

Neste sentido, o direito deve ser analisado de forma muito mais apurada e discriminatória, caso a $\operatorname{caso}^{26}$, o que afasta a adesão a um passivismo ou a um ativismo tosco, duas situações que, por caminhos distintos, poderiam levar à tirania.

Em síntese, pode-se constatar a contribuição para a teoria do direito desta nova visão a respeito do dimensionamento do Direito e da atuação do intérprete-aplicador frente a este, nota-

25 DWORKIN, Ronald. O Império do Direito. Tradução de Jefferson Luiz Camargo. São Paulo: Martins Fontes, 1999, p. 436: “[...] a equidade não pode explicar por que as pessoas agora devem ser governadas pelas minúcias das convicções políticas de pessoas eleitas muito tempo atrás, quando a moral popular, as circunstâncias econômicas e quase tudo o mais era diferente".

26 Idem, p. 452. 
damente quando Dworkin ${ }^{27}$ constrói a metáfora do juiz Hércules. De acordo com tal metáfora, um juiz ideal

[...] não é um historicista, tampouco tem o estilo aventureiro às vezes satirizado sob o epíteto de "direito natural". Ele não acha que a Constituição é apenas o que de melhor produziria a teoria da justiça e da equidade abstratas à guisa de teoria ideal [...] acredita que a Constituição norte-americana consiste na melhor interpretação possível da prática e do texto constitucionais norte-americanos como um todo, e seu julgamento sobre qual é a melhor interpretação é sensível à grande complexidade das virtudes políticas subjacentes a essa questão. [...] Ele não é um passivista, pois rejeita a ideia rígida de que os juízes devem subordinar-se às autoridades eleitas, independentemente da parte do sistema constitucional em questão. Considerará que o objeto de algumas disposições é, ou inclui a proteção da democracia, e que irá interpretar tais disposições nesse espírito, em vez de subordinar-se às convicções daqueles cuja legitimidade elas poderiam desafiar. ${ }^{28}$

Pode-se fazer referência, ainda, aos estudos de Peter Häberle, especialmente quando situa a teoria constitucional a partir de sua inter-relação cultural, bem como quando insere na análise jurídica a abertura do processo hermenêutico decorrente da ideia democrática, em que "o destinatário da norma é participante ativo"29.

27 Idem, p. 474.

28 Idem. Ibidem.

29 HÄBERLE, Peter. Hermenêutica Constitucional: a sociedade aberta dos intérpretes da Constituição - contribuição para a interpretação pluralista e procedimental da Constituição. Tradução de Gilmar Ferreira Mendes. Porto Alegre: Fabris, 1997, p. 15 e 24: “A interpretação constitucional é, todavia, uma 'atividade' que, potencialmente, diz respeito a todos. Os grupos mencionados e o próprio indivíduo podem ser considerados intérpretes constitucionais indiretos ou a longo prazo". 
Em sua teoria, resta enfatizada a importância da ideia da ampla participação social, mesmo que indireta, de todos na construção dos significantes constitucionais, alertando Häberle para o fato de que

[...] a cultura constitucional se manifesta adequadamente como moldura da categoria da 'cultura constitucional', como a soma de atitudes e de ideias, de experiências subjetivas e das correspondentes ações objetivas tanto a nível pessoal do cidadão como de suas associações, igualmente a nível de órgãos estatais e a de quaisquer outros relacionados com a Constituição, entendida esta como processo público. ${ }^{30}$

É inegável, pois, que a concepção do Direito passou por grandes transformações. A atividade interpretativa ganhou relevo, em direção à supremacia do valor democracia e da necessidade da constante averiguação da lei em face da Constituição. Destaca-se, ainda, o reconhecimento de que o Direito decorre de um procedimento que, envolvendo vários atores, acaba sendo influenciado por questões sociais externas.

Justamente por isso, os avanços da Hermenêutica Filosófica também muito contribuíram para o aprofundamento da evolução que o Direito vem sofrendo nos últimos tempos, o que ocorre em razão do questionamento das formas tradicionais de exegese, do redimensionamento do intérprete no processo hermenêutico, da evolução dos estudos sobre o papel da linguagem e de uma ampliação do próprio significado da hermenêutica.

Muller ${ }^{31}$ demonstra que a lei não contém imediatamente a norma, sendo que esta é construída pelo intérprete no processo

30 HÄBERLE, Peter. Teoria de la Constituición como Ciência de la Cultura. Madrid: Technos, 2000, p. 36-37.

31 MÜLlER, Freiderich. Métodos De Trabalho No Direito Constitucional. 2. ed. Trad. Peter Naumann. São Paulo: Max Limonad, 2000. 
de concretização do direito, o que muito se deve às incertezas, ambiguidades dos termos da lei, cuja integração se dá em um processo dialético, discursivo.

Ademais, de acordo com essa compreensão, "os textos jurídicos se limitam unicamente a oferecer pontos de partida em matéria de objetivos educacionais e valores orientadores"32, o que se atrela à ideia democrática, que remete ao fato de que "uma sociedade justa é uma sociedade onde a questão justiça permanece constantemente aberta" ${ }^{33}$.

Nestes termos, extrai-se dos estudos referidos que a norma é construída pelo intérprete no processo de concretização do direito ${ }^{34}$. "O direito, deste modo, é mais do que a lei e a jurisprudência, ou a realização jurisprudencial do direito, mais do que mera aplicação dela"35.

Somando-se à hermenêutica, a pragmática completa o que se tem denominado "giro linguístico". Warat sustenta que, utilizando do fator pragmático, o hermeneuta se insere na construção do Direito, chamando a atenção para a necessidade de desvelamento dos dogmas, bem como de um contágio do direito pelo acontecer Constitucional, que em sua doutrina, ainda não foi devidamente assimilado pelos juristas. ${ }^{36}$

No mesmo sentido, Streck esclarece que

a pragmática, terceira parte da semiótica, trata dos modos de significar, dos usos e das funções

32 HÄBERLE, Peter. Hermenêutica Constitucional: a sociedade aberta dos intérpretes da Constituição - contribuição para a interpretação pluralista e procedimental da Constituição. Tradução de Gilmar Ferreira Mendes. Porto Alegre: Fabris, 1997.

33 STRECK, Lênio Luis; MORAIS, José Luis Bolzan de. Ciência Política e Teoria Geral do Estado. 3 ed. Porto Alegre: Livraria do Advogado, 2003, p. 109.

34 Idem, p. 240.

35 NEVES, A. Castanheira. O Instituto Jurídico dos “Assentos” e a Função Jurídica dos Supremos Tribunais. Coimbra: Coimbra, 1983, p. 653

36 WARAT, Luis Alberto. Introdução Geral ao Direito I: interpretação da lei: temas para uma reformulação. Porto Alegre: Sérgio Antonio Fabris, 1994 
da linguagem. Parte-se da ideia de que fatores intencionais dos usuários provocam alterações na relação designativa-denotativa dos significados das palavras ou expressões. Isto porque, quando se utiliza uma expressão em um contexto comunicacional, esse emprego provoca uma alteração na estrutura conceitual. 0 problema dos usos das linguagens, por implicar a axiologização dos enunciados e da comunicação, não interessa ao neo-positivismo, que silencia completamente o fato de que a ideologia pode ser também considerada como uma dimensão pragmática da linguagem. A pragmática, no âmbito do Direito, trouxe enormes contribuições, mormente para as correntes críticas, permitindo a descoberta das conexões existentes entre a lei e os fatores políticos que a engendraram. Daí a impossibilidade de realizar estudos jurídicos à margem da dimensão pragmática. Fazê-lo é cair em uma atitude reducionista e cientificista. ${ }^{37}$

Essa nova visão sobre norma jurídica acaba influenciando definitivamente o processo hermenêutico, já que os princípios e as regras, em que pese cada uma das espécies conter particularidades que não vêm ao caso no presente estudo, passam a ser considerados como espécies do gênero norma jurídica. 0 que nem sempre foi assim, já que durante muito tempo os princípios exerceram tão-somente uma função filosófica de compreensão e integração do conjunto de regras ${ }^{38}$, estas sim portadoras de plena e imediata aplicabilidade.

Independentemente da filiação a uma ou outra escola, podemos depreender das breves linhas descritivas acima que o Direito efetivamente passa, na contemporaneidade, por profundas

37 STRECK, Lênio Luis. Hermenêutica Jurídica E(m) Crise - Uma Exploração Hermenêutica da Construção do Direito. Porto Alegre: Livraria do Advogado, 2004, p. 282.

38 ESPÍNDOLA, Ruy Samuel. Conceitos de Princípios Constitucionais - Elementos Teóricos para uma Formulação Dogmática Constitucionalmente Adequada. 1a ed. 2 tir. São Paulo: RT, 1999, p. 66. 
transformações. Mudaram os paradigmas que davam sustentação à visão de mundo predominante desde o modelo liberal clássico até o momento atual, tendo em vista ter sido objeto de reestruturações em razão de fatores culturais, econômicos e, inclusive, científicos ${ }^{39}$.

Resta-nos, agora, como proposta final do presente artigo buscar verificar, criteriosamente, se a denominada "Reforma Trabalhista”, especificamente no que diz respeito ao papel a ser desempenhado pelos tribunais, alinha-se a alguma das correntes contemporâneas do Direito ou, sob a falácia de modernização, implica, na realidade, um retrocesso, não apenas sob o ponto de vista social, já retratado em vários outros trabalhos, mas também sob o aspecto jusfilosófico, considerada a própria racionalidade admitida pela classe dominante.

\section{A LIMITAÇÃO DO PODER INTERPRETATIVO DO APLI- CADOR E O RETORNO AO DOGMA POSITIVISTA}

Sabe-se que Súmulas e Orientações Jurisprudenciais representam (ou pelo menos deveriam representar) a sedimentação da interpretação/aplicação reiterada dos tribunais sobre determinada matéria em um mesmo sentido. São, ou deveriam ser, portanto, o resultado da uniformização da jurisprudência, ou seja, da convergência de decisões de um órgão jurisdicional sobre determinado tema. Assim, ao restringir o alcance e dificultar excessivamente o procedimento de edição de súmulas e orientações jurisprudenciais, o legislador acaba imiscuindo-se na liberdade de interpretação/aplicação da lei.

Dentre a imensa quantidade de alterações decorrentes da "Reforma Trabalhista", no que diz respeito especificamente à possibilidade de uniformização da jurisprudência mediante a edição

39 WOLKMER, Antônio Carlos; LEITE, José Rubens Morato. Os Novos Direitos no Brasil: Natureza e Perspectivas - Uma Visão Básica das novas Conflituosidades Jurídicas. São Paulo : Saraiva, 2003. 
de súmulas e enunciados, houve duas alterações significativas: uma limitação substancial no seu conteúdo e uma exacerbada restrição formal em seu procedimento.

O parágrafo $2^{\circ}$ acrescido ao Artigo $8^{\circ}$ da CLT passou a dispor que "súmulas e outros enunciados de jurisprudência editados pelo Tribunal Superior do Trabalho e pelos Tribunais Regionais do Trabalho não poderão restringir direitos legalmente previstos nem criar obrigações que não estejam previstas em lei."

A primeira vista, o dispositivo pode até parecer interessante, uma vez que, súmulas e orientações jurisprudenciais efetivamente não deve(ria)m servir para inovar no ordenamento jurídico, mas tão-somente para sedimentar determinado entendimento sobre determinada matéria. Nesse diapasão, inclusive, vale registrar, a edição de súmulas e orientações jurisprudenciais vai ao encontro da "segurança jurídica", um dos valores sustentados pelos defensores da "Reforma Trabalhista". Mas se é assim, então por que limitar a edição de súmulas pelos tribunais trabalhistas? A razão está no que vem sendo denominado "ativismo judicial". ${ }^{40}$ E, há de se admitir que, para o bem e para o mal, efetivamente alguns enunciados vinham inovando no Ordenamento Jurídico, muitas vezes, sem sequer ser antecedido de uma única decisão no sentido da súmula editada. ${ }^{41}$

40 De acordo com Barroso, "O ativismo judicial [...] expressa uma postura do intérprete, um modo proativo e expansivo de interpretar a Constituição, potencializando o sentido e alcance de suas normas, para ir além do legislador ordinário. Trata-se de um mecanismo para contornar, bypassar o processo político majoritário quando ele tenha se mostrado inerte, emperrado ou incapaz de produzir consenso" BARROSO, Luís Roberto. Judicialização, ativismo judicial e legitimidade democrática. In: Revista Eletrônica de Direito do Estado, n. 18, abr./jun. 2009, p. 6.

41 Veja-se, por exemplo, a Súmula 331 do TST que inova o Ordenamento Jurídico ao estabelecer hipótese de subsidiariedade totalmente ao arrepio da lei e sem um único precedente. Se o leitor se der o trabalho de verificar os precedentes invocados no ato que institui a referida súmula, verá que todos são posteriores a data de sua edição e muitos deles, inclusive, fazem referência à própria súmula. O desvirtuamento na edição de enunciados jurisprudenciais chegou ao cúmulo de 
Outra tentativa de limitar o ativismo judicial dos tribunais trabalhistas foi dificultar ao máximo a própria edição e/ou alteração de súmulas no que diz respeito ao seu procedimento. De acordo com a alínea f do inciso I do artigo 702 da CLT, a criação e a alteração de súmulas e outros enunciados de jurisprudência uniforme necessitará do voto de, pelo menos, dois terços dos membros do tribunal, limitando-se a matérias que já tenham sido decididas de forma idêntica por unanimidade em, no mínimo, dois terços das turmas em pelo menos dez sessões diferentes em cada uma delas, autorizada, por maioria de dois terços de seus membros, a modulação dos efeitos. 0 parágrafo 3 o do mesmo dispositivo estabelece que "as sessões de julgamento sobre estabelecimento ou alteração de súmulas e outros enunciados de jurisprudência deverão ser públicas, divulgadas com, no mínimo, trinta dias de antecedência, e deverão possibilitar a sustentação oral pelo Procurador-Geral do Trabalho, pelo Conselho Federal da Ordem dos Advogados do Brasil, pelo Advogado-Geral da União e por confederações sindicais ou entidades de classe de âmbito nacional." 0 parágrafo $4 \stackrel{0}{ }$ estende todas essas restrições aos Tribunais Regionais do Trabalho, "com rol equivalente de legitimados para sustentação oral, observada a abrangência de sua circunscrição judiciária."

Esses dispositivos são de defesa mais difícil. Mesmo que se admita a necessidade de um número razoável de precedentes e de certa formalidade, é inegável que aqui o formalismo foi exagerado. 0 leitor já deve ter ouvido a expressão "não jogue fora a criança com a água do banho". Pois foi justamente o que o legislador reformista acabou fazendo. Sob a justificativa de limitar o ativismo judicial das cortes trabalhistas, acabou inviabi-

realizarem-se votações com a participação de juízes e advogados para a edição de súmulas e orientações jurisprudenciais, ignorando-se totalmente a existência, ou não, de algum precedente naquele sentido. Veja-se, a propósito https://www. trt4.jus.br/portais/trt4/modulos/noticias/96697. Acesso em 19 de outubro de 2016. 
lizando totalmente a edição de súmulas e enunciados destinados a uniformizar a jurisprudência trabalhista. Assim, acabou indo de encontro aos próprios objetivos da Reforma Trabalhista. Ao menos aos objetivos declarados.

É que, de acordo com as escolas hermenêuticas contemporâneas, como vimos na seção anterior, não há como interpretar/aplicar a lei sem ao mesmo tempo inovar o Ordenamento jurídico. Toda interpretação/aplicação é também uma inovação. A partir da leitura, interpretação e aplicação da lei, cria-se a norma, como demonstrado pelas diferentes escolas do pensamento jurídico contemporâneo. Tratando-se de direitos fundamentais, os direitos dos trabalhadores, em especial, constituem-se por uma estrutura materialmente aberta, e, portanto, mutável. Nesse passo, o surgimento e a consolidação de novos valores não se limita à positivação de direitos, já que estes em grande medida são produtos de uma transmutação hermenêutica e da criação jurisprudencial ${ }^{42}$.

Além disso, como corolários da dignidade da pessoa humana e de outras conquistas, os direitos fundamentais, não se abstêm de "requerer" novas formas de proteção. Assim, como já advertia Bobbio, a questão que se destaca é muito mais a de garantia de efetivação do que de fundamentação: "o problema fundamental em relação aos direitos do homem, hoje, não é tanto o de justificá -los, mas o de protegê-los. Trata-se não apenas de um problema filosófico, mas sobretudo político". ${ }^{43}$

Assim, a extrema limitação à edição e/ou alteração de súmulas e orientações jurisprudenciais acaba contrariando, não apenas, todas as correntes jusfilosóficas da contemporaneidade, mas também o próprio desiderato da "Reforma Trabahista" no

42 SARLET, Ingo Wolfgang. A Eficácia dos Direitos Fundamentais. $4^{\mathrm{a}}$ ed. rev. atual. e ampl.- Porto Alegre: Livraria do Advogado Editora, 2004. P. 61.

43 BOBBIO, Norberto. A Era dos Direitos. Tradução de Carlos Nelson Coutinho. - Rio de Janeiro: Campus, 1992. P. 24. 
que diz respeito à modernização das relações de trabalho, uma vez que impede que o Direito do Trabalho se desenvolva pelo avanço jurisprudencial.

Importa referir, aqui, para que não haja confusão, que as inovações no Ordenamento Jurídico decorrentes das decisões judiciais, edições de súmulas e outros enunciados não se confundem com as inovações decorrentes das sentenças normativas produzidas pela Justiça do Trabalho. Aquelas, inovam o Ordenamento Jurídico ao interpretar/aplicar uma norma jurídica já existente, prevista em lei, costume, ou mesmo princípio. Estas, inovam ao criar uma nova norma jurídica positivada, de aplicação restrita às categorias dos envolvidos no dissidio coletivo. Poderíamos dizer que a criação e/ou restrição de direitos e deveres no caso da sentença normativa é primária, no sentido de que envolve uma questão possivelmente não tratada por outra fonte normativa formal; ao passo que a criação e/ou restrição de direitos e deveres no caso da interpretação/aplicação e, por consequência, nos casos de edição de enunciados jurisprudenciais seria secundária, por ter de se fundar, necessariamente, em uma fonte formal de Direito que não é a própria decisão judicial.

Por outro lado, as restrições material e procedimental à edição e/ou alteração de súmulas e enunciados prejudica o ideal de segurança jurídica, na medida em que dificulta a uniformização da jurisprudência, incentivando a prolação de decisões díspares nos mais variados graus de jurisdição. Também por essa razão, as alterações legislativas conhecidas como "Reforma Trabalhista" não se coadunam com os discursos de sua defesa.

Interessante notar, a propósito, que essa limitação à edição e alteração de enunciados de jurisprudência dos tribunais trabalhistas se deu em meio à maior alteração legislativa da área desde a edição da CLT. Em que pese o texto normativo tenha sido alterado inúmeras vezes, desde sua edição, em 1943, em nenhuma dessas alterações houve tão significativo número de mudanças. Com a 
entrada em vigor da Lei 13.467/2017, mais de cem dispositivos do texto celetistas e leis esparsas foram alterados sem a devida maturação das discussões legislativas. 0 projeto inicial, de iniciativa do Poder Executivo, foi enviado para o Congresso Nacional na antevéspera do Natal de 2016 e alterava apenas 7 artigos da CLT e 8 artigos da Lei 6.019/73. Na Câmara dos Deputados, onde tramitou por apenas quatro meses, período em contou com apenas 26 horas de efetivo debate, sofreu inúmeras emendas, passando a alterar os mais de 100 artigos da CLT e legislações esparsas. Tendo passado pelo Senado Federal sem sofrer nenhuma alteração, em que pese o reconhecimento explícito de inúmeras incongruências e, inclusive, inconstitucionalidades por parte dos senadores, foi enviado para a Presidência da República, onde foi sancionado sem que recebesse os vetos esperados. ${ }^{44}$

Muitas das alterações realizadas pela "Reforma" se deram no sentido diametralmente oposto da jurisprudência consolidada pelos tribunais trabalhistas, inclusive em súmulas e orientações jurisprudenciais do TST, causando inúmeras dúvidas a todos os envolvidos com o Direito do Trabalho. É justamente nesse cenário de insegurança jurídica que o mesmo legislador restringe a edição e alteração de súmulas, tornando ainda mais tormentosa, não apenas a prática dos operadores do Direito do Trabalho, mas de todos os empregados e empregadores envolvidos nas relações trabalhistas. E é assim que, sob um discurso de "segurança jurídica” das relações de trabalho, avizinha-se um cenário de grande insegurança para todos os envolvidos nessas relações. A impres-

44 Esses números espantam em absoluto, mas espantam ainda mais quando comparados com o tempo de tramitação e debates parlamentares destinados a modificação do Código de Processo Civil (mais de 5 anos) e do Código Civil (mais de 25 anos), por exemplo. Sobre o tempo de tramitação do projeto da Reforma Trabalhista, ver NEXO. Como a Câmara aprovou mudanças em 90 artigos da CLT com 26 horas de debate. Disponível em: https:/www.nexojornal.com.br/ expresso/2017/04/27/Como-a-C\%C3\%A2mara-aprovou-mudan $\% \mathrm{C} 3 \% \mathrm{~A} 7 \mathrm{asem}-$ 90-artigos-da-CLT-com-26-horas-de-debate. Acesso em 02 maio 2017. 
são é que a coisa é feita mesmo para não funcionar, tornando as relações entre capital e trabalho cada vez mais complicadas e conflituosas. Tudo em nome de uma "desconfiança" na Justiça do Trabalho, sustentada por uma parcela do jurisdicionado que se sentiu desprestigiada por algumas de suas decisões.

Essa desconfiança no Judiciário trabalhista não se esgota na limitação da interpretação da lei e da uniformização de sua jurisprudência. Poderíamos citar, ainda, a exagerada restrição que o legislador tenta impor ao intérprete-aplicador no que diz respeito às normas coletivas, como nos casos do parágrafo $3^{0}$ do Artigo 8o da CLT e dos artigos 611 e 611-A do mesmo diploma legal. Sentimento de desconfiança que restou expresso nas palavras do presidente da Câmara dos Deputados, Rodrigo Maia (DEM-RJ), em mais de uma oportunidade. Quando condenou o número de juízes trabalhistas existentes no país (muito embora, contraditoriamente, tenha admitido o excessivo número de processos) e quando chegou ao extremo de afirmar que a própria Justiça do Trabalho não deveria existir. ${ }^{45}$ Parece claro que esse ranço contra a Justiça do Trabalho decorre de sua clara função de órgão realizador dos direitos garantidos constitucionalmente, ou mesmo da busca de ampliação de sua abrangência substancial.

Interessante notar, ainda, que essa desconfiança das cortes trabalhistas e limitação exacerbada de seus poderes vêm na contramão de outras leis, editadas pelo mesmo Congresso Nacional. Podemos citar, como exemplo, o inciso VI do parágrafo $1^{\mathrm{o}}$ do artigo 489 do CPC que, atribuindo extrema força aos enunciados jurisdicionais e precedentes, considera não fundamentada qualquer decisão judicial que deixar de seguir enunciado de súmula, jurisprudência ou precedente invocado pela parte, sem

45 Disponível em: http://www.gazetadopovo.com.br/politica/republica/maia-compra -briga-com-juizes-do-trabalho-pais-nao-precisara-mais-ter-5-mil-juizes-cnrlc7amutpdmw8gxj9uf11kn. http://www1.folha.uol.com.br/mercado/2017/03/1864822justica-do-trabalho-nao-deveria-nem-existir-diz-deputado-rodrigo-maia.shtml. Acesso em 12/01/2018. 
demonstrar a existência de distinção no caso em julgamento ou a superação do entendimento.

Afastada a questão ideológica, como se propôs na introdução desse artigo, é insofismável que a tentativa de limitação (formal e material) dos tribunais trabalhistas contraria não só as principais correntes jusfilosóficas admitidas, inclusive, pelos defensores da Reforma, mas também à própria atuação legislativa brasileira, quando não se trata de direitos dos trabalhadores. Em último caso, as alterações acabam indo de encontro aos próprios objetivos - ao menos no que diz respeito aos discursos de defesa da Reforma - de modernização e segurança jurídica.

Deste modo, entendemos que, superados os óbices levantados pela alteração legislativa, ao intérprete continua sendo imposta a tarefa de efetivação dos direitos fundamentais historicamente conquistados. Tal função remete à necessidade de uma atuação criativa e responsável, na busca da construção de soluções para os problemas que insistem em aparecer na relação entre capital e trabalho. Especialmente quando esse relação se dá em uma sociedade altamente complexa e plural. Ganha destaque, assim, a autonomia judicial. Isto porque, diversamente do modelo reducionista positivista, aplicar o Direito, nos dias atuais, é tarefa muito mais complexa do que a mera atividade silogístico-declarativa.

\section{CONSIDERAÇÕES FINAIS}

0 presente artigo teve por propósito analisar criticamente as alterações legislativas decorrentes da "Reforma Trabalhista" no que diz respeito à atividade de uniformização da jurisprudência por parte dos tribunais. Afastando-se do debate meramente ideológico, buscamos balizar nossos argumentos nas matrizes jusfilosóficas admitidas e, inclusive, adotadas pelos próprios defensores da "Reforma".

Em um primeiro momento, abordamos os avanços que o juspositivismo proporcionou a uma determinada forma de teo- 
rização do Direito. Não obstante, vimos que essa compreensão do fenômeno jurídico apresenta sérias limitações e graves problemas, que precisam ser superadas e resolvidos. Suas limitações podem ser reunidas, de forma extremamente resumida, numa compreensão inadequada do Direito como um sistema unitário, orgânico, fechado, completo e auto-suficiente. Tal limitação acaba por acarretar problemas práticos. Uma vez reconhecido como um sistema com as características acima referidas, não haveria espaço para nenhum tipo de evolução no sistema jurídico. Não foi à toa que Napoleão Bonaparte considerou o Código Civil Francês de 1804 como o seu maior legado para a posteridade.

Tal compreensão obviamente não se coaduna com um campo do conhecimento não apenas reconhecido, mas construído socialmente. A dinâmica jurídica imposta pela dinâmica social impõe, por sua vez, uma participação ativa, não apenas do legislador, mas também do intérprete-aplicador da normal. É aí que surgem as diferentes matrizes pós-positivistas, como tentativas de superação das limitações e resolução dos problemas apresentados por uma visão ultrapassada do Direito. De acordo com essas escolas, o Direito não pode mais ser visto como um sistema com as características que o juspositivismo lhe atribuíam, uma vez que, sendo fechado e aberto ao mesmo tempo, comunica-se com outros sistemas, deixando de ser, portanto, unitário, completo e autossuficiente (Niklas Luhmann).

Justamente por isso, modifica-se o papel do intérprete-aplicador. Agora não mais reconhecido apenas como a "boca da lei", ele deve se afastar tanto de um passivismo abjeto quanto de um ativismo tosco, construindo a normatividade de acordo com os significados extraídos de cada texto legal em consonância com os valores reconhecidos constitucionalmente. Dentre tais valores, ganha especial destaque a construção democrática do Direito. Impõe-se o afastamento do solipsismo jurídico e sua substituição por uma construção verdadeiramente democrática, 
com a participação ativa de todos os destinatários da norma (Peter Häberle).

Tal construção, por outro lado, não pode se resumir a uma questão de escolha da maioria. 0 próprio Estado Democrático de Direito exige que os padrões interpretativos estejam resguardados por uma coerência interna às próprias decisões. Daí a necessidade de que a edição de súmulas e outros enunciados jurisprudenciais sejam precedidas por um conjunto de decisões amadurecidas ao longo do tempo e contem com a participação das diversas instâncias julgadoras, de acordo com valores historicamente reconhecidos. (Ronald Dworkin).

Em resumo, a contemporânea compreensão do Direito não admite a extrema limitação material e formal que a "Reforma Trabalhista" pretende impor à atuação da Justiça do Trabalho, em especial quanto à edição e/ou alteração de enunciados de jurisprudência. Ao contrário, é necessário que se volte a reconhecer a importância que tais enunciados possuem na necessária evolução do Direito. De igual modo, se faz necessário um retorno para que tais enunciados voltem efetivamente a corresponder à interpretação/aplicação reiterada dos tribunais sobre determinada matéria em um mesmo sentido. Somente assim será possível a uniformização da jurisprudência trabalhista, garantindo-se, inclusive, a segurança jurídica tão desejada pelos defensores da "Reforma".

Por fim, não poderíamos encerrar esse artigo sem registrar que, como em outros vários pontos, também no que diz respeito à possibilidade de interpretação da lei e à uniformização da jurisprudência, a "Reforma Trabalhista" não importou avanço, mas um claro retrocesso. Essa "Reforma" somente poderia ser considerada uma "modernização" das relações de trabalho se por essa palavra se entendesse um retorno à Idade Moderna, época em que se acreditava que a Lei era completa e o Juiz apenas a boca que a pronunciava. 


\section{REFERÊNCIAS}

BARROSO, Luís Roberto. Judicialização, ativismo judicial e legitimidade democrática. In: Revista Eletrônica de Direito do Estado, n. 18, abr./jun. 2009.

BITTAR, Eduardo C. B.; ALMEIDA, Guilherme Assis de. Curso de Filosofia do Direito. - 2 ${ }^{a}$ ed. São Paulo : Atlas, 2002.

BOBBIO, Norberto. A Era dos Direitos. Tradução de Carlos Nelson Coutinho. - Rio de Janeiro: Campus, 1992.

BONAVIDES, Paulo. Curso de Direito Constitucional. 7ạ ed. - São Paulo: Malheiros Editores, 1997.

CAPRA, Fritjof. A Teia da Vida - Uma Nova Compreensão Científica dos Sistemas Vivos. São Paulo : Cultrix, 1996.

COMPARATO, Fábio Konder. A Afirmação Histórica dos Direitos Humanos - 2a ed. rev. e ampl. São Paulo: Saraiva, 2001.

DWORKIN, Ronald. O Império do Direito. Tradução de Jefferson Luiz Camargo. São Paulo: Martins Fontes, 1999.

ESPÍNDOLA, Ruy Samuel. Conceitos de Princípios Constitucionais - Elementos Teóricos para uma Formulação Dogmática Constitucionalmente Adequada. $1^{\mathrm{a}}$ ed. 2 tir. São Paulo: RT, 1999.

HÄBERLE, Peter. Hermenêutica Constitucional: a sociedade aberta dos intérpretes da Constituição - contribuição para a interpretação pluralista e procedimental da Constituição. Tradução de Gilmar Ferreira Mendes. Porto Alegre: Fabris, 1997.

HÄBERLE, Peter. Teoria de la Constituición como Ciência de la Cultura. Madrid: Technos, 2000.

http://www.gazetadopovo.com.br/politica/republica/maia-compra-briga-com-juizes-do-trabalho-pais-nao-precisara-mais-ter-5-mil-juizes-cnrlc7amutpdmw8gxj9uf11kn.

http://www1.folha.uol.com.br/mercado/2017/03/1864822-justica-do-trabalho-nao-deveria-nem-existir-diz-deputado-rodrigo-maia.shtml.

https://www.trt4.jus.br/portais/trt4/modulos/noticias/96697.

KELSEN, Hans. Teoria pura do direito. São Paulo: Martins Fontes, 2006.

LEAL, Mônia Clarissa Hennig. Jurisdição Constitucional Aberta: Reflexões sobre a Legitimidade e os Limites da Jurisdição Constitucional 
na Ordem Democrática - uma Abordagem a Partir das Teorias Constitucionais Alemã e Norte- Americana. Rio de Janeiro: Lumen Juris, 2007.

LUHMANN, Niklas. Legitimação pelo Procedimento. Trad. Tércio Sampaio Ferraz Jr. Brasília: Editora Universidade de Brasília, s.d..

MIRANDA, Jorge. Manual de Direito Constitucional, tomo I, 4. ed. revista e atualizada. Coimbra: Coimbra Editora Ltda., 1990.

MORAIS, José Luis Bolzan de. Do Direito Social aos Interesses Transindividuais: o Estado e o Direito da ordem contemporânea. Porto Alegre: Livraria do Advogado, 1996.

MÜLLER, Freiderich. Métodos De Trabalho No Direito Constitucional. 2. ed. Trad. Peter Naumann. São Paulo: Max Limonad, 2000.

NEVES, A. Castanheira. O Instituto Jurídico dos "Assentos" e a Função Jurídica dos Supremos Tribunais. Coimbra: Coimbra, 1983.

NEXO. Como a Câmara aprovou mudanças em 90 artigos da CLT com 26 horas de debate. Disponível em: https://www.nexojornal. com.br/expresso/2017/04/27/Como-a-C\%C3\%A2mara-aprovou-mudan\%C3\%A7asem-90-artigos-da-CLT-com-26-horas-de-debate.

REALE, Miguel. Teoria Tridimensional do Direito. - 5a ed. Ver. e aum.. - São Paulo: Saraiva, 1994. P. 62.

SARLET, Ingo Wolfang (org); FINGER, Júlio César. A Constituição Concretizada - Construindo Pontes com o Público e o Privado. Porto Alegre : Livraria do Advogado, 2000.

SARLET, Ingo Wolfang (org); FINGER, Júlio César. A Constituição Concretizada - Construindo Pontes com o Público e o Privado. Porto Alegre : Livraria do Advogado, 2000.

SARLET, Ingo Wolfgang. A Eficácia dos Direitos Fundamentais. $4 \stackrel{a}{a}$ ed. rev. atual. e ampl.- Porto Alegre: Livraria do Advogado Editora, 2004.

SOARES, Guido Fernando Silva. Common Law - Introdução ao Direito dos EUA. 2. ed. São Paulo : RT, 2000.

STRECK, Lênio Luis. Hermenêutica Jurídica E(m) Crise - Uma Exploração Hermenêutica da Construção do Direito. Porto Alegre: Livraria do Advogado, 2004, p. 282.

STRECK, Lênio Luis; MORAIS, José Luis Bolzan de. Ciência Política e Teoria Geral do Estado. 3 ed. Porto Alegre: Livraria do Advogado, 2003. WARAT, Luis Alberto. Introdução Geral ao Direito I: interpretação da 
lei: temas para uma reformulação. Porto Alegre: Sérgio Antonio Fabris, 1994.

WOLKMER, Antônio Carlos; LEITE, José Rubens Morato. Os Novos Direitos no Brasil: Natureza e Perspectivas - Uma Visão Básica das novas Conflituosidades Jurídicas. São Paulo: Saraiva, 2003. 